\title{
Climate-smart agriculture policy and (in)justice for smallholders in developing countries
}

\author{
IBNU BUDIMAN*1 \\ ${ }^{1}$ Researcher in Global Change and Global Ethics, Wageningen University, 6708 PB Wageningen, Netherlands \\ * Corresponding author: Budimanibnu26@gmail.com |+ 6285762480753
}

\section{Data of the article}

First received : 23 August 2018 | Last revision received : 17 May 2019

Accepted : 20 May 2019|Published online : 05 June 2019

doi:10.17170/kobra-2018122074

\section{Keywords}

Sustainable

Development, Rural development, Diversification, Non-farm rural activities, Rural tourism,Public-Private Partnership

\begin{abstract}
The Food and Agriculture Organization of the United Nations developed the term Climate-Smart Agriculture as an approach to transform agricultural systems to support development and ensure food security in a changing climate. This paper analyses whether climate-smart agriculture policy meets the demands of climate justice and respects the rights of smallholders; and if not, how it could be amended. The study is based on a literature review supplemented by four interviews with climate-smart agriculture actors from diverse backgrounds: a consultant, a smallholder farmer, a practitioner, and a scientist. To examine the climate-smart agriculture concept and its implementation, the following ethical positions are considered: maximalist, minimalist, Pogge's intermediate position, Nussbaum's capability approach, Kantian, and Altruist. The study finds that current climate-smart agriculture approaches are not being fairly implemented because there is the unjust sharing of benefits of income and burdens of emission reduction costs, among smallholders and agro-industries. According to the principles of climate justice, this sharing proportion should be equally distributed based on an individual's capacities and poverty should be taken into consideration as well. Climate-smart agriculture should be fair for the farmers; it should not only push and promote agribusiness expansion. The power of multinational corporations has substantially altered global agrifood chains to the detriment of small farmers and the environment. The mandatory inclusion of local, regional and national level civil society organisations and networks holds the potential for a more fair implementation of climate-smart agriculture. Climate-smart agriculture policy could be more successfully implemented if state and non-state/private sector actors would support such collaboration, allowing for decision making at local levels and a deep and honest reflection on development narratives.
\end{abstract}

\section{Introduction}

Climate change is already causing subtle changes in weather patterns that are overwhelming communities, affecting their capacity to cope with physical disasters and social disasters like chronic poverty (Comfort et al., 1999; Heltberg, Siegel, \& Jorgensen, 2009). Heltberg et al. (2009) state that climate change adaptation strategies have done little to date to address the underlying problems of vulnerability. Risk and hazard amplified by climate change are affecting the agriculture sector negatively. At the same time, industrialized agriculture is considered as one of the main drivers of climate change due to its contribution of 13 percent of total global emissions. In response, international organizations proposed the policy of climate-smart agriculture as a solution (World Bank, 2017).

The Food and Agriculture Organization of the United Nations (FAO) established climate-smart agriculture as a holistic concept that addresses agricultural development issues and other sustainable development goals 
in the context of climate change. Climate-smart agriculture purports to tackle both environmental problems and socio-economic challenges by addressing the three following elements: (i) improving crop productivity and people's incomes; (ii) increasing resilience of livelihoods; and (iii) abating greenhouse gasses (GHGs) emissions to protect ecosystems (FAO, no date, a).

Among other actors involved, some powerful actors may exploit their position when implementing climate-smart agriculture, causing further inequality and affecting farmers' rights and their welfare. For example, because of their inability to carry out climate-smart agriculture practices, climate-smart agriculture may force farmers to transfer their holdings to agribusiness companies (Taylor, 2018). On the other hand, development projects that implement climate-smart agriculture claim to target poverty reduction, food security, and economic empowerment (Steenwerth et al., 2014). These development projects may also have limitations because of the way development has become an 'industry' that often does not hold its promises; sometimes having disastrous effects (Ferguson, 1990; Moyo, 2010). Therefore, longterm, effective solutions for farmers are unlikely to be found in intervention-specific development alternatives (Escobar, 1992). Rather than project-based support for smaller groups of farmers, structural support for all farmers is required. Moreover, farmers need to be actively involved in consensual decision-making for climate-smart agriculture, because by its very nature farming is a locally-specific issue that defies one-size-fits-all solutions.

High-income countries have a duty to support vulnerable smallholders in low-income countries for various ethical reasons. For one, this duty is part of the global effort to support sustainable development (Dernbach \& Brown, 2009). Second, to make amends for colonialism and modern-day neo-colonialism. Third, developed countries import large quantities of food products from developing countries (Thøgersen, Pedersen, Paternoga, Schwendel, \& Aschemann-Witzel, 2017). Through the concept and practice of climate-smart agriculture, climate change adaptation agendas in the agricultural sector are emphasized in part to comply with ethical duty (Nunan, 2017).

In this paper, we query whether current policies and practices of climate-smart agriculture meet demands for climate justice and particularly, respect the rights of smallholders; and if not, how should policy and practice be amended. This study is a general analysis of smallholders' cases in developing countries such as in Asia (Indonesia, India, Bangladesh) and Africa (Malawi).

Chapter two describes the conceptual framework and methods utilized. Chapter three focuses on an analysis of the relationship between agribusiness, farmers and poverty, under the principle of climate justice. It presents arguments and counter-arguments for the intended outcomes of climate-smart agriculture in terms of climate justice and expectations of farmers. Chapter four discusses potential ways to transform the implementation of climate-smart agriculture. Chapter five concludes and suggests areas for further research.

\section{Methodology and Framework}

This qualitative study is based on a literature review supplemented by four interviews undertaken with climate-smart agriculture actors from diverse backgrounds (profession and countries), namely a consultant, a smallholder farmer, a practitioner, and a scientist. This small sample size is due to limited funding. The climate-smart agriculture actors were purposively selected based on their profession and experience related to climate-smart agriculture in developing countries. The consultant comes from Indonesia and has worked for ten years in agricultural development. The farmer is an Indonesian with fifteen years of farming experience. The Dutch practitioner works on environmental efficiencies and controversies about yield intensification in smallholders and agriculture production systems of South-East Asia. The Dutch scientist is a Wageningen researcher who works on agriculture, land use and greenhouse gas emissions. Each interview took between one and two hours to conduct. For ethical reasons, the actors' identities are kept anonymous.

This study assumed that each of the interviewed actors would take different ethical positions in examining the concept of climate-smart agriculture and its implementation. In this research, the following six ethical positions are considered: maximalist, minimalist, Pogge's intermediate position, Nussbaum's capability approach, Kantian, and effective altruist (table 1). These ethical positions were selected due to their relevance to the case of climate-smart agriculture.

From a maximalist viewpoint, it is obligatory to maximise general welfare and the outcome is of importance. According to this view, people intend to do their best and do not settle for less (Chappell, 2009). The minimalist viewpoint emphasizes justice and looks at how people come to own property, what types of things can be held and so forth. It focuses on the urgency of negative duties, and thus reduces all ethical questions to the principle that one can live one's life as one likes, so long as no harm is done to others .

Pogge (2001) argues that negative duties need to be managed within a theory of global justice because by 
Table 1: Ethical positions

\begin{tabular}{|c|c|c|c|c|c|}
\hline Maximalist & Minimalist & $\begin{array}{l}\text { Pogge's In- } \\
\text { termediate } \\
\text { Position }\end{array}$ & $\begin{array}{l}\text { Nussbaum's } \\
\text { Capability ap- } \\
\text { proach }\end{array}$ & Kantian & Altruist \\
\hline $\begin{array}{l}\text { Maximise gener- } \\
\text { al welfare }\end{array}$ & $\begin{array}{l}\text { Not inflict harm } \\
\text { on people }\end{array}$ & $\begin{array}{l}\text { Shape and en- } \\
\text { force social con- } \\
\text { ditions which } \\
\text { are harming the } \\
\text { global poor }\end{array}$ & $\begin{array}{l}\text { Justice is } \\
\text { grounded on } \\
\text { the individual } \\
\text { Ten human ca- } \\
\text { pabilities, inter } \\
\text { alia life, health } \\
\text { and control on } \\
\text { the environment }\end{array}$ & $\begin{array}{l}\text { Forbids us from } \\
\text { using people as } \\
\text { a mere means }\end{array}$ & $\begin{array}{l}\text { Do as much } \\
\text { good as possible }\end{array}$ \\
\hline
\end{tabular}

shaping and enforcing social conditions that foreseeably cause monumental suffering through global poverty, people are harming the global poor. These people are active participants in the largest, though not the gravest, crime against humanity ever committed (Pogge, 2001). In the capability approach by Nussbaum, justice is grounded on the individual. She states that the central human capabilities include but are not limited to the ability to live to the end of human life of normal length and to be adequately nourished. Nussbaum distinguishes ten human capabilities, inter alia life, health, and control over the environment (Nussbaum, 2009).

Kantian theory forbids the use of people as a mere means (Wood, 2007), i.e. that action is morally permissible only if it would be permissible for others to do the same act. Effective altruism is a philosophy and a social movement that aims to revolutionise the way we do philanthropy. It encourages individuals to do as much good as possible, typically by contributing money to the best performing aid and development organisations (Singer, 2015).

In this study, climate-smart agriculture is viewed as a policy narrative. Blaikie (2009) states that policy narratives are constructed by international development institutions such that public speakers may frame an issue strategically in terms of their interests and their agenda. Narratives are required to be implementable and doable by policy, hence, some facts may be used and others ignored in order to persuade people. Narratives make sense of complexity, reduce uncertainty and appeal to common sense (Blaikie, 2009). Consequently, it is crucial to reflect on narratives.

The analysis interrogates the relationship between climate-smart agriculture and expectations about development, food security in a changing climate and the reality of actual development practice. It aims to draw attention to the moral commitments of climate-smart agriculture proposals, pointing to the possibility of a radical break with the present. Empirical findings and normative perspectives are utilised together to elaborate upon climate-smart agriculture concepts and implementations.

\section{Results and Discussion}

This chapter is divided into two sections. The first section examines whether current policy and practice for climate-smart agriculture meet demands for climate justice. The second section analyses justice in relation to climate-smart agriculture development programmes and poverty.

\section{Climate-Smart Agribusiness Industries and Injustice for Smallholders}

Practices of conventional agriculture systems have led to an increase in GHG emissions and other forms of environmental degradation (Horrigan, Lawrence, \& Walker, 2002). However, there is still uncertainty about the impacts of agricultural practices on the environment (Payraudeau \& van der Werf, 2005). In order to deal with those issues, the FAO established an approach known as Climate-Smart Agriculture (CSA) through several programmes. For instance, Mitigation of Climate Change in Agriculture (MICCA) studies the life cycle assessment (LCA) of agricultural production chains by looking at mitigation opportunities, identifying the barriers of sustainable agriculture adoption at the farm level, and calculating the costs (FAO, no date, b). These studies have been conducted on some agricultural commodities and processed products in developing countries, using a concept of ecology of scale rather than economy of scale (Consultant, interview, December 12, 2017). Another FAO programme is Ex-Ante Carbon-balance Tool (EX$A C T)$. It aims at supporting the accounting process of GHG emission reductions from agricultural production. MICCA and EX-ACT provide knowledge and information to assist farmers and decision-makers to find policy options for climate change mitigation (FAO, no date, $\mathrm{c}$ ). 
The involvement of strategic decision-makers is expected to accelerate the actions for climate-smart agriculture. Therefore, the FAO promotes a collaboration of diverse stakeholders, consultants, farmers, and international development organizations, inter alia the World Bank, the Consultative Group on International Agricultural Research (CGIAR), the International Fund for Agricultural Development (IFAD), the UN World Food Programme (WFP), and the United Nations Environment Programme (UNEP). This partnership, according to the interviewed consultant, has had an impact in several countries in South Asia and Africa, but not yet in Southeast Asia.

Nonetheless, the climate-smart agriculture concept has been critiqued as being nothing less than a regime with material power that controls agricultural production, financial investment, and technology, i.e. climate-smart agriculture is being promoted to benefit multinational corporations and connected actors. As front-runners, these actors mobilise the flows of technology and finance to further build up a world agrifood system or regime (Newell \& Taylor, 2018). The transnational agribusinesses use their power to establish various supply chain certification systems as strategies to control suppliers in developing countries (Bulkeley \& Newell, 2015).

The domination of multinational corporations in climate-smart agriculture is unethical. For instance, the Global Alliance for Climate-Smart Agriculture (GACSA) initiative utilises political movements and involves private corporates to greenwash industrial agriculture (Budiman, 2016). Some of the corporates are Yara (the world's largest fertiliser manufacturer), Syngenta (GM seeds, highly hazardous pesticides), McDonald's (the hamburger chain), and Walmart. These companies are some of the planet's worst social and environmental offenders in agriculture (Deen, 2014). Chandra et al. argue that climate-smart agriculture has further marginalized vulnerable smallholders by reducing or undermining the opportunities they have to respond socio-politically to problems that include growing inequality, uneven power relations and social injustice (Chandra, McNamara, \& Dargusch, 2017). Besides, current practices of climate-smart agriculture increase the incomes of private actors and perhaps larger farmers, not the majority of smallholder farmers.

The interviewed scientist (December 5, 2017) claims that climate-smart agriculture approaches are basically common practices that farmers practised earlier; however, the focus on the reduction of emissions is an innovation. Within climate-smart agriculture approaches, the duty of emission reductions tends to burden smallholders more than the industry. Why then is climate-smart agriculture imposed more at the farm than industry level? This issue is linked to climate justice.

Climate justice links human rights and development to achieve a human-centred approach (Aminzadeh, 2006). Within climate-smart agriculture approaches, farmers have not been completely put in the centre of the approach. Hence, many climate-smart agriculture projects do not safeguard farmers' rights and do not share the burdens, benefits, and impacts of climate change equitably and fairly (Budiman, 2017). As industries possess more power and produce a higher carbon footprint compared to farmers, who should be financially responsible for climate actions to save the planet?

Developed countries are targeted under the polluter pays principle (PPP) in which the burden is placed on those who pollute. Caney (2010) argues that PPP is not appropriate for poor countries that do not have the capacity to pay. He suggests that PPP should be sensitive to such countries by considering the fact that poor farmers produce emissions because of survival reasons, to fulfil their basic needs. Thus, the burden for climate actions should not fall upon them, but rather to entities that have the greatest ability to pay (Caney, 2010).

Caney (2010) discusses climate justice in a horizontal manner, considering relations among countries, but he neglects to consider the relationship between major corporates as buyers and farmers as suppliers in the production chain. In principle, all actors in the agrifood value chain should bear the costs (burden) for climate-smart practices equally. When farmers cannot afford climate-smart agriculture practices, they should be supported by institutions and donors. Current planning of climate-smart agriculture includes the development of means to produce food with low-carbon technology. To make such climate-smart agriculture practises feasible, the interviewed scientist is of the view that the strategy should be to structurally force farmers to join larger firms. However in this way, farmers would become human labour for major agribusiness corporates and would lose their independence, rights, and control over their land and environment.

Forcing farmers to work as labour for major corporates is unethical due to the fact that it eliminates the farmers' right to enjoy their valuable functioning that links to quality of life. According to Nussbaum's concept, the set of valuable functionings that a person has effective access to is termed their capability. Thus, a person's capability represents the effective freedom (independence) of an individual to choose between different functioning combinations - between different kinds of life - that he/ 
she has reason to value.

Nevertheless, farmers in India claim that climate-smart agriculture helps them to protect their crops from climate change (Khatri-Chhetri, Aggarwal, Joshi, \& Vyas, 2017; VoA News, 2016). The interviewed scientist claims that climate-smart agriculture works and that it is unethical to allow farmers to farm in an unsustainable way. Emitting a great amount of GHGs causes environmental problems that limit the rights of other people. The interviewed scientist argues that statements like "poor farmers want their children to become farmers" romanticise farmer poverty, rather than enhance their capability to develop.

The interviewed practitioner (December 12, 2017) challenged the interviewed scientist's claims by saying that farmers are victims of bigger regimes of economics and politics, including the regimes global capitalism and more recently, climate change. Before these regimes emerged, farmers' practices had been sustainable. Then these regimes came along with corresponding agricultural policies that introduced high input agriculture systems. Nowadays, farmers have adopted intensified agricultural practices, and have contributed immensely to food security; though nonetheless small farmers have not received a fair price for their products. Despite this, the current regimes want to (again) reform farmers' behaviour in terms of climate change. Therefore, farmers are continually steered by massive regimes that are beyond their control, and thus are arguably not the ones to be blamed. Are bigger political regimes responsible? The United Nations Climate Change Conference (UNFCCC), Paris COP 21, lacked discussions about serious strategies for climate-smart agriculture (Saikawa, 2015). The non-legally binding commitments may contribute to further climate injustice in terms of agricultural stress and food insecurity. In addition, the target of sticking to a 1.5-2.0-degree global temperature increase, as stated in the Paris agreement, is projected to endanger water resources and agricultural production. In the Paris agreement, there is no provision to cover farmers' loss and damage from climate disasters (Weiskel, 2016).

Accordingly, farmers have become more impoverished and vulnerable. In the name of food security, the world's most powerful actors, who look for the most efficient way to produce food, have welcomed agrifood firms and technologies. Thus, where is the justice? Or have these powerful actors already redefined justice? These powerful actors' plans are unethical because they are harming others, namely farmers who possess low bargaining power and often lose in this kind of battle.
The current climate-smart agriculture concept is powered by strong capitalist actors that affect the way justice is conceptualised within existing climate-smart agriculture arrangements. There is a gap between its policies and practices that may lead to unintended effects. Mosse (2004) presumes that these unintended effects are neither necessarily perverse nor hidden. This effect may serve to ensure that farmers remain impoverished, especially in developing countries (Budiman, 2016). If the capitalist regime continues unabated, effective development programmes need to be developed as explained in the following section.

\section{Climate-Smart Agriculture, Development Programmes, and Poverty among Farmers}

Most people residing in rural areas of developing countries live in extreme poverty while managing small farms (UN, 2011). One valid question, therefore, is whether climate-smart agriculture as part of climate change mitigation can become a driver of farmers' decisions, particularly if mitigation efforts do not lead to short-term increases in farmer income or welfare (Mbow et al., 2014). There is a connection between climate-smart agriculture, poverty reduction, development programmes, and economic development (Steenwerth et al., 2014).

Nunan (2017) argues that current climate-smart agriculture development programmes do not change practices on the ground. She critiques the fact that climate-smart agriculture targets thousands of small farm businesses each working in different conditions and with individual farmer behaviours. This causes the technical effectiveness and adaptation measures of climate-smart agriculture (CSA) to be uncertain or questionable. Sharma \& Suppan (2011) are critical of the limited understanding of the CSA concept and its practical designs, and of the absence of a monitoring methodology (Sharma \& Suppan, 2011). Governments may avoid creating policy in this sector where implementation and monitoring for uncertain outcomes may be costly. Accordingly, smallholders may be unable to sustain climate-smart agriculture activities in the long-term due to its uncertain economic impacts (Fröhlich, Schreinemachers, Stahr, \& Clemens, 2013). Are these obstacles conquerable? For this, we should have a closer look at developing countries and their circumstances.

Many developing countries receive development aid. Therefore, some organisations are concerned that climate-smart agriculture will become a condition for the receipt of development aid. Considering the above-mentioned uncertainties in the climate-smart agriculture approach, its programmes as with any other development projects may fail (Shames et al., 2012). Smallholders have 
neither an asset base nor surplus capital to compensate for project failures. Therefore, there is a need to re-examine the feasibility of climate-smart agriculture projects implemented through development programmes.

Climate-smart agriculture development (CSA) programmes have failed and even led to increased vulnerability among smallholders in several countries. In Malawi, where a strong strategy for developing agroforestry (as a component of climate-smart agriculture) is in place, a development programme could not solve its governance problems due to a dichotomy among government bodies. Forestry departments are usually mandated to multiply and disseminate all types of tree germplasm. While, environment departments dislike regulated rows, intensive management and chemical control of weeds. This conflict led to an increase in the expenditure of human labour to clear weeds (FAO, 2013). In Bangladesh, a development programme failed to change farmers' behaviour from using chemical fertilizer to organic fertilizer ('interviewed practitioner, interview, December 12, 2017). In Indonesia, a development programme could not convince the government to provide subsidies for organic fertilizers (Osorio, Abriningrum, Armas, \& Firdaus, 2011).

Non-governmental organizations (NGOs) are one of the key actors in CSA development programmes. NGOs primarily promote climate-smart agriculture with a view to enhance the capacity of agricultural systems to support food security and climate mitigation (FAO, no date, d). Have NGOs accomplished their purpose? The FAO (no date, d) states that there is no one-size-fits-all blueprint for how climate-smart agriculture should be pursued. Roe (1991) shows that blueprints are undergirded by narratives, and argues that the reason we do not learn more from past development efforts is precisely the reason we cannot better plan for the future (Roe, 1991). Currently, few countries in Africa and the Association of Southeast Asian Nations (ASEAN) have created a blueprint for climate-smart agriculture (Saj et al., 2017). To operationalize it, attention should be given to coordination between national and local stakeholders.

The lack of operational blueprints is one key reason that explains why climate-smart agriculture development programmes do not really reach poor farmers (Taylor, 2018). From a Kantian viewpoint the actions of development programmes should not be judged according to their consequences, but by their intention. The rightness or wrongness of development programmes depends on whether they fulfil their ethical duty.

What is the ethical duty of development programmes?
According to Escobar (1992), development discourse creates ways of thinking about poverty and ways of designing programmes in order to alleviate poverty. Experts have proposed different strategies, rooted in local histories and traditions, for the improved implementation of development programmes (Leimgruber, 2018). Indeed thirty years ago Escobar (1992) argued that development has to be redefined and this insight is still relevant today in the case of climate-smart agriculture. This illustrates how little progress has been made in the past few decades.

Climate-smart agriculture does not redefine agricultural 'development'. The interviewed scientist states that climate-smart agriculture is not as novel as it seems to be. Mitlin, Hickey and Bebbington (2007) acknowledge public opinion as the key arena in which dominant views can be contested and argue that counter-hegemonic alternatives may require actors from outside and within the state, not only NGOs. Currently, NGOs participate in policymaking at the global level in terms of climate change; however, their operational experience is their strong point (Mitlin et al., 2007). This may allow us to use the development concept differently in the future in order to achieve the intended outcomes.

In the last decade, a number of economic publications have stressed the counterproductive consequences of development aid (Easterly, 2008; Moyo, 2010). Common concerns include the idea that development aid feeds a cycle of dependence in recipient countries, promotes corruption and constitutes a barrier to developing countries taking responsibility for their own economic and social development. Transforming institutional capability in utilising aid is hence needed.

Based on the premise of climate-smart agriculture implemented in the current 'development industry', climate-smart agriculture within development programmes is incommensurate with effective altruism (Singer, 2015). An act to help farmers is correct if and only if it is an act that, among all the acts available to the stakeholders, maximizes the overall interest-satisfaction among all affected farmers.

Both the interviewed scientist and practitioner argue that being poor is not an excuse not to contribute to climate-smart agriculture. The interviewed farmer, however, stresses that poor farmers are foremost concerned with their survival. Escobar (2002) shows that the development discourse creates the impression that the poor must be treated and reformed (Escobar, 2002). However, our findings show that the development discourse on climate-smart agriculture fails to seriously consider ways 
to eradicate poverty.

By definition and principle, climate-smart agriculture is necessary for the environment and development. However, the current implementation of climate-smart agriculture in developing countries as promoted does not support a just development for farmers. Inequality in the current implementation strategies of climate-smart agriculture may contribute to impoverishing farmers rather than the opposite. The existing climate-smart agriculture approaches do not meet the demand for climate justice. Farmers are still left behind. Climate-smart agriculture ignores farmers' capabilities to effectively farm and to own land. The power of big corporates in climate-smart agriculture eliminates the freedoms of farmers to enjoy their valuable functioning, hence, more attention on farmers' capabilities is advisable (Robeyns, 2011).

How then can climate-smart agriculture be ethically implemented? A dialogical process that allows arguments and counter-arguments is required for just and equitable outcomes from climate-smart agriculture to eradicate poverty among smallholders. To reach an acceptable argument may occupy much time. In the meantime, alternative strategies such as governance reform and introducing win-win practices can be considered. This topic is explained in the following chapter.

\section{Revising Climate-Smart Agriculture}

A revision of climate-smart agriculture policy and practice is required to ensure farmers' rights. This section focuses on the second part of our research objective, exploring the potential opportunities to improve justice in the implementation of climate-smart agriculture and to increase economic resilience for farmers.

\section{Revisiting Governance}

The interviewed consultant suggests a need for a change in food production and in generating livelihoods in terms of climate-smart agriculture. Regarding the responsibility of reducing emissions, LCA (life cycle assessment) may be useful and may identify which activities or which actors, e.g. industry, farmers, or consumers, should be held responsible for emissions. The industry level as the richest actor has the greatest ability to pay for emission reduction costs. As a powerful actor, it has the means to facilitate a structural change in climate-smart agriculture implementation.

According to Pogge, global institutions have established the rules and regulations that benefit the interests of developed countries over developing nations. This leads to the moral criticism of rich groups exploiting their bar- gaining power intellectually and economically to shape new forms of imperialism (Pogge, 2005). This global order neglects smallholders' capacity in developing countries. In the case of climate-smart agriculture, the FAO and its alliance can be viewed as a set of global institutions that perhaps inadvertently advance the interests of the giant agri-food industries of developed countries. This governance structure needs to be reconsidered.

Costs to reduce emissions in the agricultural sector are a burden for developing countries and will most likely disturb any attempts to reduce poverty. Current climate-smart agriculture threatens smallholders' access to their farms and to their basic human rights (Sonderholm, 2012). Nowadays, farmers are not solely producers of food but they have also become consumers of food produced by big agri-food industries. Recent climate agreements may form a new geopolitics of food security as a response to uneven food supply and its distribution. Some developed countries have even used agricultural land and resources to produce bioenergy. Given the levels of hunger in poor countries, this can be considered a violation of human dignity (Weiskel, 2016).

This paper argues that governance needs to be changed to create a fair system of food production and trade. Yet, it may not be easy to change global governance. Climate-smart agriculture is most obviously a type of market-based solution that involves businesses in climate governance. Bulkeley \& Newell (2015) argue that globalization has increased the participation of businesses in climate governance and as such, has endorsed broader shifts from the state to market power. One of the key sectors in business is finance, e.g. the insurance industry works with leading banks, and climate-smart agriculture promotes climate insurances. However, this insurance may not benefit farmers, rather it can cause more risk to farmers if they fall in debt.

Another problem with the governance of 'climate-smart' agriculture (CSA) is that the corporates and managerial technocrats do not take a holistic view. Climate change is a major issue, but it's not the only one. The planetary boundaries concept considers nine environmental situations that should be considered (SEI, 2009). One of them is biodiversity which is at breaking point. Current solutions proposed under CSA won't protect the biodiversity of insects and the entire food web.

The governance of climate-smart agriculture should emphasise voluntarism and networks of partnerships of civil societies and farmer groups, in contrast to neo-liberal modes of governance. The following section presents an example of a more fair network of governance for cli- 
mate-smart agriculture.

\section{Redefining Development Programmes}

Chandra et al. (2017) show that three socio-political processes, namely inequality, unequal power relations and social injustice, make smallholders significantly vulnerable. They suggest that climate-smart agriculture development programmes need to embed renewed concepts of equality, power relations, and social justice into both policy and practices of climate-smart agriculture. Agroecology could be an example of a development programme on climate-smart agriculture (CSA) that applies all three concepts. Agroecology addresses local risks, specificities, and the priorities of smallholders. This practice is aligned with Nussbaum's approach to respecting farmers' capability.

Since CSA has a rather strong focus on policies, institutions, and financing, without having a specific blueprint for climate-smart practices, agroecology actually responds to the needs of climate-smart agriculture in terms of site-specificity and potential for adoption by farmers because it is strongly based on local practices. Agroecology combines farmers' knowledge and their culture with modern scientific findings. It is a sustainable farming practice that returns $\mathrm{CO} 2$ to the soil, reducing about a quarter of all current global GHG emissions (Saj et al., 2017). Through family farms that are rich in biodiversity, often on collective territories, agroecology nourishes people and heals broken ecosystems. In this sense, climate justice and food sovereignty are acts of political resistance. They exist outside the corporate control of the food systems (Budiman, 2017b), most likely alleviating farmers' poverty.

To implement climate-smart agriculture approaches, agroecology can be governed through collective farming to incentivize farmers (Matthews, 2015). The main incentive expected by farmers is an increase in income, usually facilitated by collaborations in the governance model of cooperatives. All four interviewees were positive about collective actions of cooperatives to sustainably grow and support food production, and to achieve climate-smart agriculture objectives. However, they emphasize that these collective actions should not reduce farmers' sovereignty, because land ownership allows farmers to retain their independence and remain at least partly independent of big industries. Cooperatives are a form of good governance to improve agri-food value chains.

Technological innovations in climate-smart agriculture, according to the interviewed consultant, are viewed as barriers for farmers. To solve this issue, collaborations in cooperatives need a successful innovation that is partly dependent on effective business models that are used to diffuse innovative technology (Long, Blok, \& Poldner, 2016). Moreover, such a business model can link the collaboration with consumers. Results of LCA studies show that high emissions are caused by consumers due to their preference for certain products, and that firms claim that they produce products that are demanded by consumers. Ethical production and consumption need to be promoted within climate-smart agriculture.

In addition, cooperation among international development programmes is required to support agroecology cooperatives. With reference to effective altruism (Singer, 2015), different approaches may be combined to optimise the utilisation of climate-smart agriculture approaches, to significantly enhancefarmers' livelihoods.

\section{Conclusion and Recommendations}

The current climate-smart agriculture policy and approaches are not fairly implemented, due to injustice in sharing benefits of income and burdens from emission reduction costs, among farmers and industries. According to the principle of climate justice, that proportion should be equally distributed based on an individual's capacities and taking into consideration poverty. Industries have a greater ability to pay for emission reduction costs. Likewise, farmers must also farm sustainably.

Implementation of climate-smart agriculture can be analysed from the six ethical positions utilised in this study. The industries use the maximalist viewpoint that maximises general welfare and the importance of the outcome. Actors in the agrifood industries intend to do the best (for themselves) and do not settle for less. The industries perceive their action as just and fulfilling the urgency of negative duties. This is also aligned to the minimalist viewpoint where one can live one's life as one likes, so long as no harm is done to others. Yet the industries do not manage their negative duties within a theory of global justice, because through the current implementation of climate-smart agriculture, they have been shaping and enforcing social conditions that foreseeably cause monumental suffering through global poverty, and in the process are harming poor farmers. Justice is grounded on the individual. The central farmer capabilities (inter alia life, health, and control over the environment) include but are not limited to the ability to live to the end of human life of normal length and to be adequately nourished. Climate-smart agriculture should not be utilised by the industries to use farmers as a mere means.

A reflection on development narratives may facilitate a successful implementation of climate-smart agriculture. This narrative should be constructed in a dialogical pro- 
cess that allows arguments and counter-arguments, resulting in just and equitable outcomes to eradicate poverty among smallholders.

To enforce justice in the implementation of climate-smart agriculture, its governance dominated by big food regimes of transnational companies will have to be transformed. Alternatively, we have argued that renewing development programmes through agroecology may hold the promise of justice in climate-smart agriculture for farmers. This movement should be utilised to encourage individuals to do as much good as possible. Multiple stakeholders can unite to support these movements. It can be done by contributing money to the best performing aid and development organisations.

Revising the governance of climate-smart agriculture through agroecology and farmers cooperatives would likely change the direction of the current climate-smart agriculture approaches. Climate-smart agriculture should be promoted to achieve a just transition for different groups of people and the environment. These modalities are required to actualize climate-smart agriculture policy as part of the notion of sustainable development to balance economic development, environmental protection, and social equality.

Further research is required on two topics. First, on how the capitalists/beneficiaries of the current global order justify their version of climate-smart agriculture. Second, on the governance model required to manage a fairer climate-smart agriculture.

\section{Acknowledgements}

I would like to thank Anna Seidel, Henk van den Belt, the interviewees, and LPDP (Indonesia Endowment Fund for Education) for your support to this paper.

\section{Conflict of Interests}

The authors hereby declare that there are no conflicts of interests.

\section{References}

Aminzadeh, S. C. (2006). A moral imperative: The human rights implications of climate change. Hastings International and Comparative Law Review, 30(2), 231-265.

Blaikie, P. M. (2009). The tsunami of 2004 in Sri Lanka: An introduction to impacts and policy in the shadow of civ- il war. Norsk Geografisk Tidsskrift - Norwegian Journal of Geography, 63(1), 2-9. doi:10.1080/00291950802712061

Bradshaw, T. K. (2007). Theories of poverty and anti-poverty programs in community development. Community Development, 38(1), 7-25. doi:10.1080/15575330709490182

Budiman, I. (2016, November 4). Climate-smart agriculture not an oxymoron. The Jakarta Post. Retrieved from http://www.thejakartapost.com/news/2016/11/04/ climate-smart-agriculture-not-oxymoron.html

Budiman, I. (2017, August 14). ASEAN after 50: Climate justice and smallholder farmers. Retrieved from http:// asc.fisipol.ugm.ac.id/asean-50-climate-justice-smallholder-farmers/

Bulkeley, H., \& Newell, P. (2015). Governing climate change (2nd ed). New York: Routledge.

Callahan, D. (1981). Minimalist ethics: On the pacification of morality. In A. L. Caplan, \& D. Callahan (Eds.), Ethics in hard times (pp. 261-281). Boston, MA: Springer. doi:10.1007/978-1-4684-4022-5 9

Caney, S. (2010). Climate change and the duties of the advantaged. Critical Review of International Social and Political Philosophy, 13(1), 203-228. doi:10.1080/13698230903326331

Chandra, A., McNamara, K. E., \& Dargusch, P. (2017). The relevance of political ecology perspectives for smallholder Climate-Smart Agriculture: A review. Journal of Political Ecology, 24(1), 821-842. doi:10.2458/ v24i1.20969

Chappell, T. (2009). Ethics and experience: Life beyond moral theory (1st ed). McGill-Queen's University Press https://doi.org/10.4324/9781315711676

Comfort, L., Wisner, B., Cutter, S., Pulwarty, R., Hewitt, K., Oliver-Smith, A., Wiener, J., Fordham, M., Peacock, W., \& Krimgold, F. (1999). Reframing disaster policy: The global evolution of vulnerable communities. Global Environmental Change Part B: Environmental Hazards, 1(1), 39-44. doi:10.3763/ehaz.1999.0105

Deen, T. (2014, September 24). Climate-Smart Agriculture is Corporate Green-Washing, Warn NGOs. IPS News. Retrieved from http://www.ipsnews.net/2014/09/ climate-smart-agriculture-is-corporate-green-washingwarn-ngos/

Dernbach, J. C., \& Brown, D. A. (2009). The ethical re- 
sponsibility to reduce energy consumption. Hofstra Law Review, 37, 985-1006.

Easterly, W. (2009). Can the West save Africa? Journal of Economic Literature, 47(2), 373-447. doi:10.1257/ jel.47.2.373

Escobar, A. (1992). Imagining a post-development era? Critical thought, development and social movements. Social Text, (31/32), 20-56. doi:10.2307/466217

Escobar, A. (2002). The problematization of poverty: The tale of three worlds and development. In S. Schech, \& J. Haggis (Eds.) Development: A cultural studies reader (pp. 79-92). Oxford: Blackwell.

FAO (no date, a). Climate-smart agriculture. Retrieved from http://www.fao.org/climate-smart-agriculture/en/ FAO (no date, b). Mitigation of climate change in agriculture (MICCA) programme. Retrieved from http:// www.fao.org/in-action/micca/en/

FAO (no date, C). EX-ante carbon balance tool (EX-ACT). Retrieved from http://www.fao.org/tc/exact/ex-acthomelen/

FAO (no date, d). Economic and policy analysis of climate change. Retrieved from http://www.fao.org/climatechange/epic/home/en/

FAO (2013). Advancing agroforestry on the policy agenda - A guide for decision-makers (Agroforesting Working Paper no.1). Rome. Retrieved from http://www.fao. org/fsnforum/ar/resources/fsn-resources/advancing-agroforestry-policy-agenda-guide-decision-makers

Farming First (2011). The story of agriculture and the green economy. Retrieved from https://farmingfirst.org/ green-economy/

Ferguson, J. (1990). The anti-politics machine: "Development", depoliticization and bureaucratic power in Lesotho. Cambridge: Press Syndicate of the University of Cambridge.

Fröhlich, H. L., Schreinemachers, P., Stahr, K., \& Clemens, G. (2013). Sustainable land use and rural development in southeast Asia: Innovations and policies for mountainous areas. Springer Science \& Business Media.

Heltberg, R., Siegel, P. B., \& Jorgensen, S. L. (2009). Addressing human vulnerability to climate change: Toward a 'no-regrets' approach. Global Environmental Change, 19(1), 89-99. doi:10.1016/j.gloenvcha.2008.11.003
Horrigan, L., Lawrence, R. S., \& Walker, P. (2002). How sustainable agriculture can address the environmental and human health harms of industrial agriculture. Environmental Health Perspectives, 110(5), 445-456. doi:10.1289/ehp.02110445

Khatri-Chhetri, A., Aggarwal, P. K., Joshi, P. K., \& Vyas, S. (2017). Farmers' prioritization of climate-smart agriculture (CSA) technologies. Agricultural Systems, 151, 184-191. doi:10.1016/j.agsy.2016.10.005

Leimgruber, W. (2018). Between global and local: marginality and marginal regions in the context of globalization and deregulation. Routledge.

Long, T. B., Blok, V., \& Poldner, K. (2016). Business models for maximising the diffusion of technological innovations for climate-smart agriculture. International Food and Agribusiness Management Review, 20(1), 5-23. doi:10.22434/IFAMR2016.0081

Matthews, A. (2015). Matthews incentivising climate smart agriculture on Irish farms. Food. Retrieved from https://www.slideshare.net/amtthews/matthews-incentivising-climate-smart-agriculture

Mbow, C., Van Noordwijk, M., Luedeling, E., Neufeldt, H., Minang, P. A., \& Kowero, G. (2014). Agroforestry solutions to address food security and climate change challenges in Africa. Current Opinion in Environmental Sustainability, 6, 61-67. doi:10.1016/j.cosust.2013.10.014

Mitlin, D., Hickey, S., \& Bebbington, A. (2007). Reclaiming development? NGOs and the challenge of alternatives. World Development, 35(10), 1699-1720. doi:10.1016/j. worlddev.2006.11.005

Mosse, D. (2004). Is good policy unimplementable? Reflections on the ethnography of aid policy and practice. Development and Change, 35(4), 639-671. doi:10.1111/ j.0012-155X.2004.00374.x

Moyo, D. (2010). Dead aid: Why aid makes things worse and how there is another way for Africa. Penguin Books. Retrieved from $\mathrm{http}: / / \mathrm{cms}$.medcol.mw/cms_uploaded_resources/4685_4.pdf

Newell, P., \& Taylor, O. (2018). Contested landscapes: the global political economy of climate-smart agriculture. The Journal of Peasant Studies, 45(1), 108-129.

Nunan, F. (2017). Making climate compatible development happen. New York: Routledge. 
Nussbaum, M. C. (2009). Frontiers of justice: Disability, nationality, species membership. Cambridge: Harvard University Press.

Osorio, C. G., Abriningrum, D. E., Armas, E. B., \& Firdaus, M. (2011). Who is benefiting from fertilizer subsidies in Indonesia? The World Bank. Retrieved from https://elibrary.worldbank.org/doi/abs/10.1596/1813-9450-5758

Payraudeau, S., \& van der Werf, H. M. (2005). Environmental impact assessment for a farming region: a review of methods. Agriculture, Ecosystems \& Environment, 107(1), 1-19.

Pogge, T. (2001). Priorities of global justice. Metaphilosophy, 32(1/2), 1-5. doi:10.1111/1467-9973.00172

Pogge, T. W. (2005). Human rights and global health: a research program. Metaphilosophy, 36(1-2), 182-209. doi:10.1111/j.1467-9973.2005.00362.x

Priambodo, A., \& Kumar, S. (2001). Energy use and carbon dioxide emission of Indonesian small and medium scale industries. Energy Conversion and Management, 42(11), 1335-1348.

Robeyns, I. (2006). The capability approach in practice. Journal of Political Philosophy, 14(3), 351-376.

Roe, E. M. (1991). Development narratives, or making the best of blueprint development. World Development, 19(4), 287-300.

Saikawa, E. (2015, December 16). A win for air quality in Paris summit, but climate-smart agriculture still lags. The Conversation. Retrieved from http://theconversation.com/a-win-for-air-quality-in-paris-summit-but-climate-smart-agriculture-still-lags-52240

Saj, S., Torquebiau, E., Hainzelin, E., Pages, J., \& Maraux, F. (2017). The way forward: an agroecological perspective for Climate-Smart Agriculture. Agriculture, Ecosystems \& Environment, 250, 20-24.

SEI (2009, September 17). The nine planetary boundaries. Retrieved from https://www.stockholmresilience. org/research/planetary-boundaries/planetary-boundaries/about-the-research/the-nine-planetary-boundaries. html

Shames, S., Wollenberg, E. K., Buck, L. E., Kristjanson, P. M., Masiga, M., \& Biryahwaho, B. (2012). Institutional innovations in African smallholder carbon projects. CCAFS Report 8. Copenhagen, Denmark: CCAFS.
Sharma, S., \& Suppan, S. (2011). Elusive promises of the Kenya agricultural carbon project. South Minneapolis: Institute for Agriculture and Trade Policy. Retrieved from https://www.iatp.org/documents/elusive-promises-kenya-agricultural-carbon-project

Singer, P. (2015). The most good you can do: How effective altruism is changing ideas about living ethically. New Haven: Yale University Press.

Sonderholm, J. (2012). Thomas Pogge on global justice and world poverty: A review essay. Analytic Philosophy, 53(4), 366-391.

Steenwerth, K. L., Hodson, A. K., Bloom, A. J., Carter, M. R., Cattaneo, A., Chartres, C. J., ... Horwath, W. R. (2014). Climate-smart agriculture global research agenda: Scientific basis for action. Agriculture \& Food Security, 3(1), 11.

Taylor, M. (2018). Climate-smart agriculture: What is it good for? The Journal of Peasant Studies, 45(1), 89-107. Thøgersen, J., Pedersen, S., Paternoga, M., Schwendel, E., \& Aschemann-Witzel, J. (2017). How important is country-of-origin for organic food consumers? A review of the literature and suggestions for future research. British Food Journal, 119(3), 542-557.

UN (2011). World Economic and Social Survey 2011: The great green technological transformation. Department of Economic and Social Affairs, United Nations. Retrieved from https://www.un.org/en/development/desa/ policy/wess/wess_current/2011wess.pdf

VoA News (2016, August 11). Indian farmers battle with climate smart agriculture. VOA News. Retrieved from https://www.voanews.com/a/indian-farmers-battle-with-climate-smart-agriculture/3460162.html

Weiskel, T. (2016, March 20). What comes after Paris COP21...? Agricultural stress $==>$ Food insecurity and $==>$ the demand for climate justice." Retrieved from https://www.cctvcambridge.org/node/383914

Wood, A. W. (2007). Kantian ethics. New York: Cambridge University Press.

World Bank (2017). Climate-smart agriculture. Retrieved from http://projects-beta.worldbank.org/en/results/2017/11/29/climate-smart-agriculture 